\title{
Entrelacs
}

Cinéma et audiovisuel

HS | 2012

Le post-humain et les enjeux du sujet

\section{Polymorphie du corps post-humain}

Ophélie Hernandez

\section{OpenEdition}

Journals

Édition électronique

URL : http://journals.openedition.org/entrelacs/292

DOI : 10.4000/entrelacs.292

ISSN : 2261-5482

Éditeur

Éditions Téraèdre

Édition imprimée

Date de publication : 2 février 2012

ISBN : 978-2296567177

ISSN : 1266-7188

Référence électronique

Ophélie Hernandez, «Polymorphie du corps post-humain », Entrelacs [En ligne], HS | 2012, mis en ligne

le 01 août 2012, consulté le 23 avril 2019. URL : http://journals.openedition.org/entrelacs/292 ; DOI :

10.4000 /entrelacs.292

Ce document a été généré automatiquement le 23 avril 2019.

Tous droits réservés 


\title{
Polymorphie du corps post-humain
}

\author{
Ophélie Hernandez
}

1 Le texte complet de cet article est publié dans l'ouvrage :

Post humain et les enjeux du sujet

Editeur : L'HARMATTAN (2 février 2012)

Collection Ouverture Philosophique

ISBN-10 : 2296567177

ISBN-13 : 978-2296567177

\section{RÉSUMÉS}

Les images produites par notre Société du Spectacle, en diffusant les dogmes du « jouir » et de la polymorphie du corps, participeraient à la fabrication d'une post-humanité, paradoxalement basée sur un projet de désincarnation physique et psychique.

\section{AUTEUR}

\section{OPHÉLIE HERNANDEZ}

Psychologue clinicienne, chargée d'enseignement et doctorante sous la direction de Murielle Gagnebin à l'université Paris III. Elle a réalisé un film autobiographique à partir de l'analyse et du remontage de ses vidéos de famille et un essai documentaire à partir de vidéos de familles collectées dans divers milieux sociaux et culturels. 